\title{
Development of Thematic Teaching Materials Based on Discovery Learning in Elementary School
}

\author{
Nur Wahyuni ${ }^{1 *}$, Lala Jelita Ananda ${ }^{1}$ \\ Department of Primary School Teacher Education, Faculty of Teacher Training and Education, Medan \\ State University, Medan, Indonesia \\ *acunwahyuni10@gmail.com
}

Received: November $04^{\text {th }}, 2020$

Revised: March 03 ${ }^{\text {rd }}, 2021$

Accepted: March 09 ${ }^{\text {th }}, 2021$

\begin{abstract}
The purpose of this research is to develop teaching materials using the discovery learning model to improve thematic learning outcomes in elementary schools. This research aims to develop thematic teaching materials based on the discovery learning model for fourth grade students of elementary school and to describe the feasibility of thematic teaching materials products based on the discovery learning model. This type of research is research and development (R\&D). The development model used is the ADDIE (Analysis, Design, Develop, Implementation and Evaluate) model. The results of research on thematic teaching materials based on discovery learning are from the results of assessments carried out by media experts, material experts and students' responses during field trials. The results of the validation show that the overall score is 3.7 so that it is included in the "very good" category and the overall eligibility percentage is $93 \%$ so that it is included in the "very appropriate" category. Based on the above explanation, it can be concluded that the thematic teaching materials are based on discovery learning are suitable for learning for fourth grade students of elementary school.
\end{abstract}

Keywords: development; discovery learning; teaching materials.

\section{INTRODUCTION}

Education is a process of effort, influence, protection, and assistance intellectually and emotionally towards nature and fellow humans as a provision towards adulthood in order to achieve the highest safety and happiness. Education is also the most important thing for every human being so that his life becomes focused and more advanced in facing challenges in the future.
Primary school is the most basic level of formal education for children to develop logical thinking so that their intellectual abilities can be trained. Elementary school is also a level of education that must be directed at the aspects of attitude, cognitive, psychomotor and skills. This is in accordance with the applicable curriculum, namely 2013 Curriculum. Curriculum 2013 carries a balance between attitudes, knowledge, and skills 
to build soft skills and hard skills starting at the levels of Elementary School, Junior High School, and Senior High School, the learning process in the 2013 curriculum is packaged in the form of themes or thematic learning.

In implementing the 2013 curriculum, the government provides learning resources to carry out classroom learning using teacher books and student books. Teaching materials are all materials that are arranged systematically from various sources for the learning process, both written and unwritten, to make it easier for teachers and students in the classroom to make the learning process enjoyable.

Prastowo (2015: 17) says that "teaching materials are all materials (both information, tools, and text) that are arranged systematically, which displays a complete figure of competencies that will be mastered by students and used in the learning process with the aim of planning and reviewing implementation. learning ". If the preparation of teaching materials does not meet the criteria and is not systematically arranged, problems will arise in the learning process in the classroom (Putra, Witri, \& Yulita, 2019; Satria \& Hajani, 2020).

In developing teaching materials, one of the things that must be considered is that the language used must be easy to understand, especially for the elementary school level so that it can be understood by students and must also be in accordance with the needs of students such as characteristics and social environment.

Based on observations made by researcher in October 2019 at Elementary School during apprenticeship I and II. Only 2 teachers of 12 teachers developed teaching materials in the learning process in class, but the teachers who developed these teaching materials did not use the learning model, only combined the appropriate materials. The teaching materials available at Elementary School are very limited, especially for thematic learning using only one book. When students work on questions in the textbook, many students feel confused because they only use one source of the book and the language in the textbook is not understood by students.

In addition, researcher also observed the learning process that took place there were deficiencies in the teaching materials used by teachers at SD Negeri 053969 Mancang, including: (1) the teaching materials made by the teacher had not used a learning model that made the learning process excited. This can be seen when the learning process takes place there are still many students who do not pay attention to the teacher's explanation and many play in the class so that the class becomes noisy, (2) the teacher does not understand how to develop teaching materials according to the proper procedures and criteria, (3) learning is still dominated by the teacher so that learning seems monotonous and no one asks students even though there 
are still many who do not understand the lesson.

Based on the results of the observation of the documentation study, the average score of the first semester tests of thematic learning at SD Negeri 053969 Mancang in 2019 in grade IV, there are still many who have not completed or met the criteria and are classified as low. The results of the tests were only 10 students who achieved the maximum completeness criteria, between 72-85, while the other students scored far below the maximum completeness criteria, namely only 50-66. The low student learning outcomes above indicate that students' lack of understanding of the teaching material in thematic learning. This can be used as a consideration by the teacher to try to improve student learning outcomes in thematic subject matter.

Based on the above problems, the researcher feels the need to develop teaching materials that can make students interested in carrying out the learning process in the classroom so that learning can be carried out well and learning objectives can be achieved. The development of teaching materials will be made more complete, interesting, easy to understand, and in accordance with the needs of students. It is hoped that by developing teaching materials learning activities can run well and be interesting and run effectively and efficiently for students so that learning outcomes can increase.

In addition to creating interesting teaching materials, it is also necessary to develop teaching materials made using appropriate learning models. This is used so that teachers better understand how to teach properly and also make students have increased interest in learning.

The learning model used in this study is a learning model based on Discovery Learning . It is hoped that by developing thematic- based teaching materials based on Discovery Learning, students can find concepts and principles through their own understanding process. The concepts and principles found must be written clearly. In finding concepts, students make observations, classify, make assumptions, explain, draw conclusions and so on to find some concepts or principles in the thematic teaching material.

\section{RESEARCH METHODS}

The type of research used in this research is research and development known. Research and Development aims to produce and develop a product with a development model, namely ADDIE . The subjects of this study were fourth grade students of SD Negeri 053969 Mancang Langkat. Sources of data in this development research are experts, namely material experts, design expert, grade IV teachers and fourth grade students of SD Negeri 053969 Mancang .

In this development research, the types of data taken are qualitative data and quantitative data. At the product validation stage, the data obtained were qualitative data in the form of criticism, suggestions, and validator responses in improving Discovery Learning -based 
thematic teaching materials. Quantitative data is obtained from statements in providing product assessments, namely the level of validity and feasibility of products during product trials. This study adapted the ADDIE development model consisting of five stages that include the analysis, design, development, implementation and evaluation (Sugiyono, 2015: 200).

In research, there are several commonly used data collection methods. The data collection methods are interviews, observation, questionnaires, and documentation studies. The data collection instrument in this development is in the form of an assessment instrument to assess the products that have been developed. Principal instruments used by researchers to collect data in this development are as follows.

Collecting data in this study used several instruments which were divided based on the source of data collection consisting of needs analysis instruments, expert validation instruments, and validation instruments with field trials. The research and development instruments are in the form of interview and questionnaire instruments. The interview instrument was used to analyze the needs of teachers and students on the use of teaching materials for fourth grade elementary school students. The questionnaire sheet contains statements that are prepared to see the feasibility of learning media made by researchers. The validation instrument in the form of a questionnaire / questionnaire will be filled in by media experts and material experts. The validation instrument with field trials was filled by teachers and fourth grade students of SD Negeri 053969 Mancang.

Data analysis technique is the process of systematically searching and compiling data obtained from interviews, field notes and documentation. By organizing data into categories, describing it into units, synthesizing, arranging into patterns, choosing which ones are important and what will be studied, and making conclusions so that they are easily understood by oneself and others (Sugiyono, 2017: 335).

\section{RESULTS AND DISCUSSION}

This research is a type of research development. The development of this teaching material uses the ADDIE ( Analysis, Design, Development, Implementation, Evaluation) model . All stages in this development model have been carried out according to plan.

The first stage is the analysis stage. At the analysis stage, the researcher conducted a needs analysis, student analysis, and material analysis. This stage of analysis is carried out to obtain information and collect data. When conducting a needs analysis, the researcher collected data by conducting interviews with the fourth grade homeroom teacher at SD Negeri 053969 Mancang. Based on the results of the interview, teaching materials have not been used optimally due to the limitations of teaching materials that use the learning model. The teacher only 
uses student books and pictures posted on the wall in delivering learning materials. Researchers conducted a student analysis by observing the activities of students in the learning process. Therefore, the analysis stage is needed as a basis for developing learning media that suits your needs.

The second stage is the design stage. At this stage the researcher compiles a plan for making thematic teaching materials based on Discovery Learning on sub-theme 1 I and learning ideals 1 and 2 . The researcher collects materials in the form of the preparation of teaching materials, and the collection of appropriate materials. After that the researcher designed the media design then collected the materials used in making Discovery Learning -based thematic teaching materials according to the predetermined design.

The third stage is the development stage. At this stage the researchers began to make products, namely thematic teaching materials based on Discovery Learning . After the teaching materials have been made, the product is validated by two validators, namely design experts and learning material experts. Validation is carried out to obtain assessments and input on thematic teaching materials based on Discovery Learning that have been developed. The suggestions given by design experts are; 1 . Must be consistent in the use of color, for example, for the coloring of KD in Indonesian, it is red on page vi, then it should be red for those related to Indonesian, etc. 2 . Must be consistency of Images, Sequences and colors, Let's Observe, Come Ask Come on, gather information, Come on Try it, Come on Communicate, Come on, let's practice (the inviting sentence or the command line) and adjust it to the Discovery Learning syntax. For example in lesson 1 "Come on ask", in lesson 2 "Come on, answer questions!". 3. One page of instructions for using teaching materials, such as Let's Ask: in this activity students are asked to ask questions. 4. The development of this teaching material is more likely to be like LKPD due to the number of tasks and exercises, it needs to be supported by, 1) concept maps, 2) supporting reading materials accompanied by attractive and realistic pictures as a real depiction of clear references.

Meanwhile, material experts provide suggestions, namely; 1 . There are still many misconceptions. 2. The layout needs to be developed. 3 . Adjust KD with Indicators. 4. The selection of images must be considered and include sources. 4. A lot of spelling needs to be improved. 5. Formulation of indicators according to the level of competence in KD. 6. Image resolution needs to be improved. 7 . Spelling / punctuation needs to be improved in several aspects. 8. There are several sentences that are not standard.

Furthermore, after the teaching material has been validated, the researcher revises the product. Product revisions are made based on suggestions and comments given by experts. Researchers made revisions according to the suggestions of design experts and 
material experts. After the teaching materials have been revised in accordance with the suggestions given, the products that have been developed can be tested on students.

The fourth stage is the implementation stage. At this stage, the thematic teaching materials based on Discovery Learning that have been validated will be tested on fourth grade students of SD Negeri 053969 Mancang. At this stage the researchers introduce thematic teaching materials based on Discovery Learning and practice how to learn teaching materials. Furthermore, the researcher gave a questionnaire to see the students' responses to the thematic learning materials based on Discovery Learning that had been developed. However, product testing cannot be done in its entirety. Overall product testing could not be carried out due to circumstances that made it impossible in the midst of the COVID-19 pandemic which resulted in face-to-face teaching and learning activities in schools being temporarily suspended until an undetermined time. Therefore, researchers only conducted small group trials of 5 grade IV students who lived in an adjacent house. Previously, this had received approval from the principal, homeroom teacher, parents of students, and students to carry out trial activities in the midst of the COVID-19 pandemic.

The fifth stage is the evaluation stage. The evaluation carried out is in the form of development evaluation and evaluation of the feasibility of thematic teaching materials based on Discovery
Learning that have been developed. Evaluation of the development and feasibility of thematic teaching material products based on Discovery Learning is carried out by design expert lecturers and learning material expert lecturers as well as students. The assessments and responses given by the experts and students will be accumulated as a whole. The results of the evaluation will provide data and describe the thematic teaching material products based on Discovery Learning whether they are appropriate or not suitable for use as teaching materials in class.

The feasibility analysis of thematic teaching materials based on Discovery Learning that was developed can be seen from the assessment by design experts, material experts and the responses given by students during product trials. Product feasibility analysis can be seen based on the assessment of each stage that has been carried out by experts and students. Based on table 4.8, the validation score by media experts is 3.7 with the "Very Good" category, then the validation score by material experts is 3.6 with the "Very Good" category, then the score obtained during the product trial is 3.8 with category "Very Good" The average obtained based on the results of the media validation as a whole was 3.7 with the "Very Good" category. Based on table 4.9 the percentage of product eligibility by design experts was obtained by $93 \%$ with the "Very Feasible" category, the percentage of product eligibility by material experts was obtained by $90 \%$ with the "Very 
Feasible" category, then the percentage of product eligibility at the time of product testing to students was obtained $97 \%$ in the "Very Eligible" category. The average percentage of eligibility results as a whole is $93 \%$ and is included in the "Very Eligible" category.

The following are teaching material products developed with the Discovey Learning model with ADDIE stages : (1) Analyze , (2) Design , (3) Development, (4) Implementation , (5) Evaluation (Evaluation).

\section{CONCLUSSION AND SUGGESTION}

Research and development of thematic teaching materials based on Discovery Learning on sub-theme 1 and the aspirations for learning 1 and 2 in grade IV SD Negeri 053969 Mancang have been completed in accordance with the steps and stages of research and development. Based on the results of research and development that has been carried out by researchers, it can be concluded that:

This research and development has produced a product in the form of thematic teaching materials based on Discovery Learning using the ADDIE model with the following steps:

(1) Analyze ,

(2) Design

(3) Development ,

(4) Implementation

(5) Evaluation .

Thematic teaching materials based on Discovery Learning that have been developed have been validated by design expert validators, with a final score of 3.7 in the "Very Good" category. Based on the score obtained, the percentage of eligibility is $93 \%$ in the category of "Very Appropriate". Based on the results of validation by design experts, the thematic teaching materials based on Discovery Learning are suitable for use in the learning process in the classroom.

Thematic teaching materials based on Discovery Learning that have been developed have been validated by material expert validators with a final score of 3.6 in the "Very Good" category. Based on the score obtained, the eligibility percentage is $90 \%$ with the category "Very Appropriate". Based on the results of validation conducted by learning material experts, thematic teaching materials based on Discovery Learning are suitable for use in the learning process in the classroom.

Thematic teaching materials based on Discovery Learning that have been developed have been tested on fourth grade students of SD Negeri 053969 Mancang with an eligibility percentage of $97 \%$ with the category "Very Feasible". Based on the results of students' responses to thematic teaching materials based on Discovery Learning, the thematic teaching materials based on Discovery Learning are appropriate for use in the learning process in the classroom.

Based on the results of the research that has been done, the researchera propose the following suggestions. The availability of teaching materials can help students understand the learning 
material being taught and can also improve learning outcomes. Thematic teaching materials based on Discovery Learning can be used as a learning resource for students in the learning process, and this supports the previous studies by Rahmadhani, Yunisrul \& Helsa (2020).

Thematic teaching materials based on Discovery Learning can be used to make it easier to understand learning materials, especially in sub-theme I and my aspirations for learning 1 and 2 in grade IV SD students. Researchers also suggest further research and development in order to develop teaching materials in other materials.

\section{REFERENCES}

Arikunto, S. (2012). Basics of Educational Evaluation. Jakarta: Earth Literacy.

Hamdani. (2011). Teaching and Learning Strategies. Bandung: Faithful Library.

Hapsari, Y. (2011). Improving the Ability to Play Role Playing Using Jigsaw Techniques and VCD Drama Media for Class VIII C Students of SMP Negeri 01 Kangkung, Kendal Regency, Academic Year 2010/2011. Essay. Publication. Semarang: UNNES.

Illahi, T. M. (2016). Learning Discovery Strategy and Metal Vocational Skills. Yogyakarta: DIVA Press.

Irwanti, E. (2017). Development of Free Writing Teaching Materials for Class VIII SMP Xaverius Tugumulyo. Journal of Language Studies,
Literature and Teaching (KIBASP), $1(1), 32-49$.

Lestari, I. (2013). Competency-Based Teaching Materials Development . Jakarta: Permata Academy.

Majid, A. (2014). Integrated Thematic Learning. Bandung: Youth Rosdakarya.

Munasik, M. (2014). The Ability of Primary School Teachers In Implementing Thematic Learning in Primary Schools . Journal of Education 15(2).

Murfiah, U. (2017). Integrated Learning (Theory \& Best Practice in Schools). Bandung: Refika Aditama.

Nana, N. (2010). Assessment of Teaching and Learning Process Results. Bandung: Youth Rosdakarya.

Piety, P. (2017). Development of Mathematics Teaching Materials Based on Discovery Learning Learning Models to Improve Students' Concept Understanding of the Subjects of Class XI Class XI MAN 1 Makassar. Thesis: UIN Alauddin Makassar.

Prastowo, A. (2015). Creative Guide to Making Innovative Teaching Materials. Yogyakarta: Diva Press.

Putra, Z. H., Witri, G., \& Yulita, T. (2019). Development of Powerpoint-based learning media in integrated thematic instruction of elementary school. International Journal of Scientific \& Technology Research, 8(10), 697-702.

Rahmadhani, S., Yunisrul, Y., \& Helsa, Y. (2020). Discovery Learning Model in Integrated Thematic Learning for 
Elementary School Students. Tunjuk Ajar: Jurnal Penelitian IImu Pendidikan, 3(2), 202-209.

Rivai, A. (2015). Development of Instruction-Based Learning

Materials with Picture Posters for High School Students. Thesis: Semarang State University.

Sani, A. R. (2017). Scientific Learning for the Implementation of the 2019 Curriculum. Jakarta: Earth Literacy.

Satria, T. G., \& Hajani, T. J. (2020). Development of Thematic Skill Learning Based on the 21st Century Skill Model for Fourth Graders. Journal of Teaching and Learning In Elementary Education, 3(1), 47-57.
Siska, S. (2019). Development of Student Team Achievement Division (STAD) type of cooperative teaching materials on the theme of my ideals in Class IV Semester II SD Negeri 112137 Rantauprapat in the 2018/2019 academic year. Thesis: State University of Medan.

Sugiyono, S. (2016). Educational Research Methods. Bandung: Alfabeta.

Widiasworo, E. (2017). Teaching Students Outside Keas (Outdoor Learning). Yogyakarta: Ar-Ruzz Media. 